\title{
The influence of the frequency of biology practical classes and biology teachers' qualification on senior school students' knowledge of biological drawings
}

\author{
David Akinjide Akintola ${ }^{\text {a, }}{ }^{1}{ }^{*}$, Gabriel Olawumi Ayanlola a, ${ }^{2}$, Musa Mohammed Sulaiman ${ }^{\text {b, } 3}$ \\ a Department of Science Education, Faculty of Education, National Open University of Nigeria, Lagos, \\ Nigeria \\ ${ }^{\mathrm{b}}$ Department of Science Education, Faculty of Education, University of Ilorin, Ilorin, Nigeria \\ ${ }^{1}$ akinjide17@gmail.com *; ${ }^{2}$ gabrielayanlola@gmail.com; ${ }^{3}$ sulaiman.mm@unilorin.edu.ng \\ * Corresponding author
}

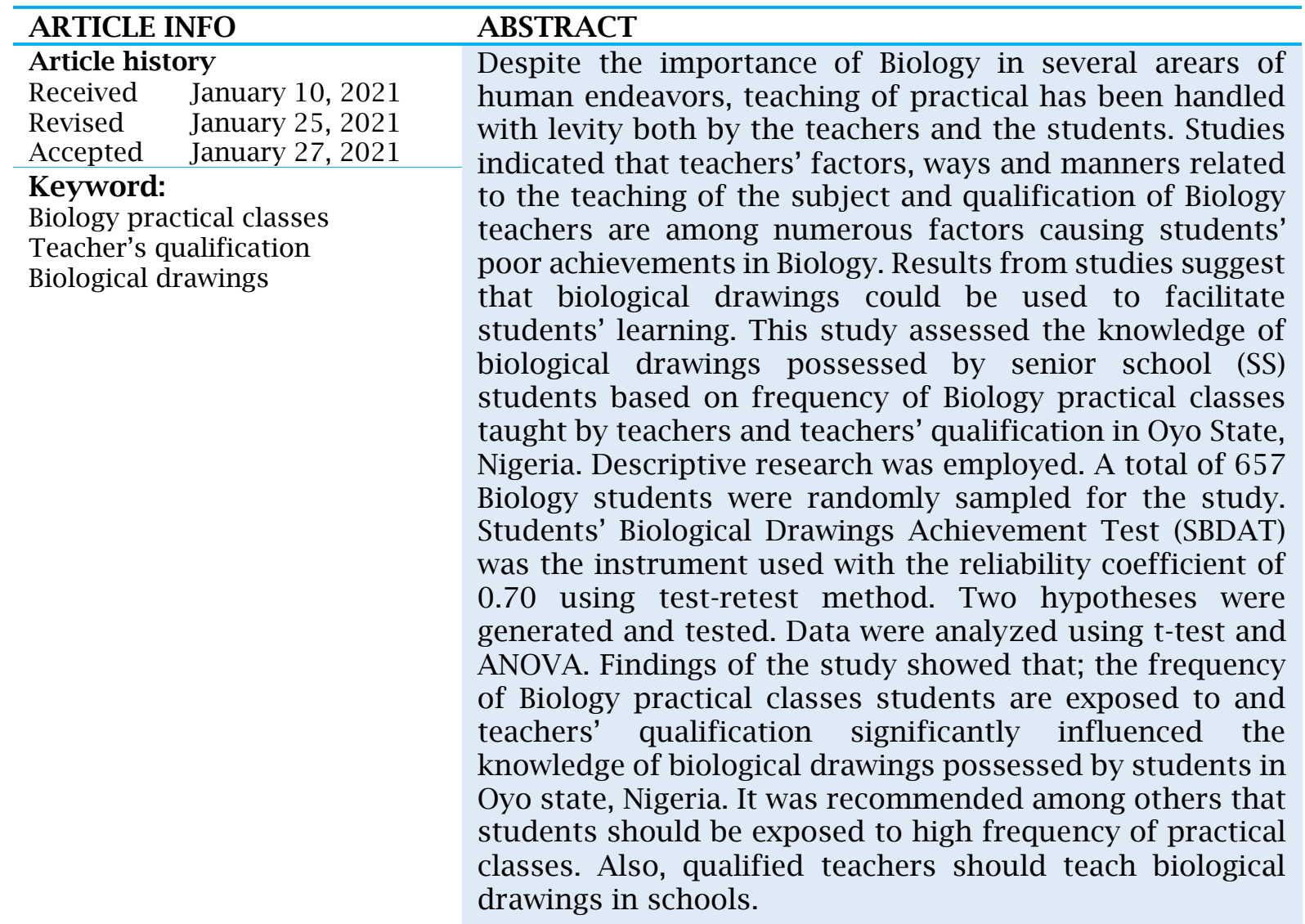

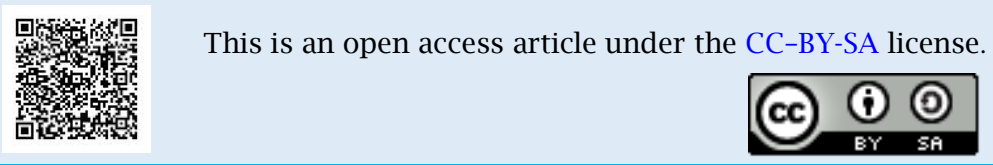

\section{Introduction}

Science and technology are inevitable forces in the current drive towards a guarantee of good life, peace, security and survival of humankind. Science curricula mainly aim to help students acquire related knowledge and skills (Demir et al., 2007) and to train science/technology-literate individuals (Taşdemir \& Demirbaș, 2010). Akintola et al. (2018) affirmed that the prestige and political power of any nation reside in its level of scientific activities since science is the key that unlocks the door to the modern development. Furthermore, Olagunju et al. (2003) 
remarked that the relevance of science to national goals, aspiration and economy dictate, to a large extent, the huge commitment and support, which most nations make and give to science and technological development" (p.219).

Importance of science and technology had led governments, private organizations and individuals to invest in the teaching of science and scientific researches, particularly in Nigeria, to promote, hold and sustain the interests, needs and aspirations of our children, youths and teachers in science (Gbore, 2013). Such a hopeful desire might be hindered by the surging students' underachievement, outrageous development of anti-science culture, evolution of scientifically illiterate citizenry, despicable school and home conditions. All the mentioned menace contributed to secondary school science students steady worst performance recorded in the school certificate biology examinations (Kirschner \& van Merriënboer, 2013).

Koba and Tweed (2009) indicated that students achieved poorly in Biology in both internal and external examinations. The West African Examinations Council (WAEC, 2014, 2015, 2016, 2017, 2018) Chief Examiner's Reports revealed a persistently poor achievement of biology students in public examinations as a result of student's weaknesses in the areas of labelling, title and drawings among others. Teacher's characteristics have been identified as a part of the important factors contributing to student's achievement in biology. Teacher's qualifications and frequency of biology practical classes are variables of interest of the researcher in this study.

Biology practical is an important part of biology. It allows more vivid and intimate interaction among the students, teachers, specimens and other relevant materials. This interactions during the practical classes make a shift from teacher centered approach to students' centered approach. According to Kolucki and Lemish (2011), learners do practical to expand their knowledge for the purpose of understanding their environment. In biology, more than 50\% of student's examination questions in biology comprises of drawings (Akintola et al., 2018). For students to have good grades in biology, the student must be very skillful in drawings which are mostly taught during practical classes.

Watt et al., (2013) claimed that, performances of students improve in science when they are taught practical. The frequency of biology practical classes taught by the teacher implies the number of times the teacher goes to class to teach students biology practical with particular reference to biological drawings. The frequency of biology practical classes could be low, moderate or high (Akintola \& Ayanlola, 2019). Literatures reviewed showed that most teachers prefer teaching biology and other science subjects theoretically neglecting the practical teaching, few ones that teach practical do it partly (Okoli, 2006). It was discovered that most biology teachers give biological drawings to students as an assignment or employ the services of fine arts, geography or male teachers as the case may be to help them produce the drawings for students on the chalkboard not minding that biological drawings are different from; mathematical, artistic, architectural and geographical drawings among others (Akintola \& Ayanlola, 2019).

Motlhabane's (2014) finding revealed that students taught biology practical frequently have good knowledge of biological drawings than the students taught sparsely or at low frequency. Motlhabane (2014) also reported that most of biology practical equipment is kept under lock and key by the school principals. Also, some science teachers are so much occupied with administrative work and handled teaching of biology practical with levity. It was also observed that some schools failed to include biology practical on the school time table.

Ebubedike (2010) opined that the achievement of senior secondary school biology students in Enugu north local government area was low because teachers did not teach enough practical topics in the sampled schools. According to Uche (2010), most biology teachers placed more emphasize on theoretical aspect of biology leaving the practical undone. Sequel to the various observations about the ways and manners biological practical is been taught, the researcher considered it imperative to study the influence of frequency of biology practical classes in relation to students' knowledge of biological drawings in senior schools in Nigeria. 
The qualification of biology teachers is an important factor in teaching and learning of biology in schools. Omosewo (2010) investigated the effects of teachers' academic qualifications on senior secondary students' performance in physics and discovered that teachers' academic qualifications were a necessity for students' performance in physics. Maagan (2007) stated that 63\% of the sciences teachers in Israel had no formal qualification of their subjects.

Mubenga (2006) states that there has been a serious discrepancy in the academic achievement of minority students which are black compared with the achievement of white students. The observed differences were associated to the disparities among the qualifications and quality of teachers that taught the two categories of the students.

In the study of Tournaki et al. (2009), titled "Teachers' qualifications and students' achievement in urban elementary school", teachers' academic success and specific characteristics influence classroom outcomes. The study examined whether teacher licensure test-scores and other attributes affect elementary students' achievement. The results were based on longitudinal students' level data from Los Angeles. The results showed large difference in teachers' quality across the school district; also, teachers' characteristics explained little of the difference in teachers' licensure test scores and are unrelated to teachers' success in the classroom. Similarly, students' achievement was unaffected by whether classroom teachers had advance degrees or not.

The result of Khurshid's (2008) study concluded in wale city (Pakistan) which was delimited to two male government and private schools and three female private and government schools with eighty students and eighty-seven teachers as sample showed that the performances of the students taught by the untrained teachers with B.A/B.Sc. qualifications were better than the students taught by trained teachers with professional qualifications like B.Ed. and M.Ed. The subjects used were English, Islamic studies, Pakistan studies, Math's, Physics, Chemistry and Biology.

In the study of Fakeye (2012) in Ibarapa division of Oyo state on students' achievement in English language, the results showed that the teachers' teaching qualifications had a significant relative contribution on students' academic achievement in English language. Also, the finding of Omosewo and Abimbola (2007) showed that the teachers' academic qualifications were a necessity for students' performances in physics at the secondary school level of education.

Another relevant study is the work of Krieg (2005) which concluded that gender, teachers' qualifications and laboratory facilities affect students' performance in physics. In the studies of Owolabi and Adedayo (2012) that examined the effects of teachers' qualifications on the performance of senior secondary school students in physics, it was discovered that students taught by teachers with high qualifications performed better than those taught by teachers with lower qualifications.

Lerner (2007) studied the relationship between teachers' qualifications and students' performances in technical subjects in selected schools in Northern Nigeria. The researcher used questionnaire for data collection and records of school document about students' performance. Descriptive statistics were used to analyze the data. The result showed that, teachers' qualification affected students' performance in external WASSCE (technical).

Among the notable studies on Teacher's qualification and students' performance is the work of Akinsolu (2010) with Twenty-one sampled public schools in Osun state, Nigeria. The data collected were ANOVA. The results of the study showed that teachers' qualifications, experience and teacher-student ratio were significantly related to students' academic performance. The needs for our educational planners to employ qualified teachers to facilitate teaching and learning in our secondary schools was compulsory.

The study of Buddin and Zamaro (2009) reflected that teachers' qualifications test scores were unrelated to students' achievement and also not affected by whether classroom teachers had advanced degree; however, students' achievement increased with teachers' experience. More so, Oyelekan et al. (2017) opined that educational products were not only determined by the quality of the material input (knowledge skill) but also by the quality of those who implemented and supervised those inputs (the teachers). The 
researcher claimed that what students at all levels aimed and achieved intellectually depended largely on what their teachers taught, how those were taught and the faith future which the teaching job was concluded. Hence, teachers' qualification is a variable of interest in relation to students' knowledge of biology in senior schools in Nigeria.

\section{Statement of the Problem}

The knowledge of concept of drawing is essential to the understanding of various aspect of biology such as Embryology, Anatomy, Physiology Genetics, cytology, Botany, Zoology, Parasitology and other science disciplines such as medicine, agriculture, genetics, engineering, physics, chemistry and biology.

Understanding of a particular organ, its functions, faults, remedy and every related factor depend on having pictorial or diagrammatic knowledge of such organ. (Akintola \& Ayanlola, 2019). Also, biological drawings covered over $50 \%$ of questions in biology examinations. This aspect is taught in biology practical class.

Motlhabane's (2014) study on practical work revealed that the conditions in secondary schools were not satisfactory for doing practical work. Schools that have been provided with equipment do not make much use of it. Some expensive apparatus and equipment which have never been used, were found deteriorating in storerooms and boxes in many of the schools visited. The researcher stated that at schools where the equipment was available, teachers claimed that the school system did not allow enough time to do practical work. This is because teachers spend a lot of time doing administrative work and spend little or no time on practical work. Many of the teachers prefer to do demonstrations, which are very teacher-centered. Hence, the need to assess the knowledge of biological drawings possessed by senior school students as a component of practical work in senior school biology is pertinent. Despite the importance of drawing in biology as revealed in the WAEC chief examiners' reports from 2003 to 2014, a persistent poor achievement of biology students in public examinations was shown to stem from students' weaknesses in the areas of labelling, title and drawing. Poor achievement of students was also discussed in the WAEC (2014) Chief Examiners' Report in May/June biology essay and alternative to practical's examinations, poor drawing skills and poor drawing and labelling were identified as areas of weakness of the students. In addition, most of the studies carried out in biology were on practical works generally and not mainly focused on Biological drawings.

\section{Research Hypotheses}

The following research hypotheses were tested in this study:

$\mathrm{HO}_{1}$ There is no significant difference between the frequency of biology practical classes given by the teacher and the knowledge of biological drawings possessed by the students.

$\mathrm{HO}_{2}$ There is no significant difference between teachers' academic qualifications and the knowledge of biological drawings possessed by the students.

\section{Method}

The research type that was adopted for this study was the descriptive research of the survey type. A descriptive research investigates and reports the way things are. Since this study was meant to survey the knowledge of biological drawings possessed by senior school students, the survey method was considered relevant and appropriate for this study. The population for this study was all senior secondary school two (SS2) biology students in Oyo State, Nigeria.

Twenty senior secondary schools were randomly sampled for the study. From the 20 sampled schools, purposive sampling technique was used to select a total of 657 SS2 biology students in relation to frequency of biology practical classes and teachers' academic qualification. All of the 20 SS2 biology teachers from the sampled schools were selected for the study. The sample was from the school that had been present students for SSCE examinations for more than five year. Also, schools where the drawing contents for this study have been taught.

The research instrument for this study includes Students Biological Drawings Achievement Test (SBDAT) drawn from WASSCE and NECO (SSCE) Biology syllabus (WAEC, 2018). The teachers Biodata were also collected. The instrument was given both face and content validity by experts in biology, biology practical and biological drawings, respectively. Reliability index of o.7 was obtained using test-retest method. 
Students were requested to draw six biological drawings; Amoeba, Cockroach, Tilapia, Toad, Flamboyant flower and transvers section of tomato fruit. The answer scripts were marked by Ten WAEC examiners and vetted by two team leaders. The areas marked were; correct title, horizontal labelling, size, clarity of lines, details and labelling. A mark or point is allotted to each area. A total of 15 marks is allotted to each drawing. Influence of teachers' qualifications on students' knowledge of biological drawings was rated via comparing the achievement of students taught by qualified biology teachers and those taught by unqualified biology teachers in biological drawings achievement test. Hypothesis one was analyzed using ANOVA while hypothesis two was analyzed using t-test.

\section{Results and Discussion}

Results and discussions were made based on the analyzed data.

$\mathrm{HO}_{1}$ There is no significant difference between frequency of biology practical classes by the teacher and the knowledge of biological drawings possessed by the students.

Table 1 presents the results of the analyses of students' knowledge of biological drawings in senior schools based on frequency of biology practical classes taught by the teaching Oyo state, Nigeria. The results showed in Table 1 implied that $\mathrm{p}=.0001$ was significant. It indicates that the frequency of biology practical classes influences the knowledge of biological drawings possessed by senior school students in Oyo state, Nigeria. Therefore, the null hypothesis which stated that there was no significant difference between frequency of biology practical classes by the teacher and the knowledge of biological drawings possessed by the students was rejected.

Table 1. One way analysis of variance of knowledge of biological drawings of students based on frequency of biology practical classes

\begin{tabular}{llllllr}
\hline & Sum of squares & df & Mean squares & F & Sig. & Remark \\
\hline Between groups & 17202.937 & 2 & 8601.469 & 99.06 & .000 & Rejected \\
Within groups & 56873.320 & 655 & 86.829 & & & \\
Total & 74076.257 & 657 & & & & \\
\hline
\end{tabular}

As a result of the post-hoc test (Tukey HSD), it was discovered that students exposed to high frequency of biology practical classes performed better than students exposed to medium and low frequency of biology practical classes. Furthermore, students exposed to medium frequency of biological drawings also performed better than students exposed to low frequency of biological drawings. The finding of this study is in agreement with the results from the studies: Motlhabane (2014) that students taught biology practical frequently have good knowledge of biological drawings than the students taught sparsely or at low frequency; Ebubedike (2010) opined that the achievement of senior secondary school biology students in Enugu north local government area was low because teachers did not teach enough practical topics in the sampled schools; and Uche (2010) which revealed that most biology teachers placed more emphasize on theoretical aspect of biology leaving the practical undone.

Table 2. Post-hoc test (Tukey HSD) on the knowledge of biological drawings possessed by senior school students exposed to low, medium and high frequency of biology practical

\begin{tabular}{|c|c|c|c|c|}
\hline $\begin{array}{c}\text { (I) Frequency of Biology } \\
\text { Practical Classes }\end{array}$ & $\begin{array}{c}\text { (J) Frequency of Biology } \\
\text { Practical Classes }\end{array}$ & $\begin{array}{l}\text { Mean } \\
\text { Difference (I-J) }\end{array}$ & $\begin{array}{l}\text { Std. } \\
\text { Error }\end{array}$ & Sig. \\
\hline \multirow[t]{2}{*}{ High } & Medium & $-4.205 *$ & 1.462 & .012 \\
\hline & Low & $6.965 *$ & 1.384 & .0001 \\
\hline \multirow[t]{2}{*}{ Medium } & High & $4.205^{*}$ & 1.462 & .012 \\
\hline & Low & 11.170 & 0.806 & .0001 \\
\hline \multirow[t]{2}{*}{ Low } & High & $-6.965 *$ & 1.364 & .0001 \\
\hline & Medium & 11.170 & 0.806 & .0001 \\
\hline
\end{tabular}

* The main difference is significant at the 0.05 level 
The results on Table 2 showed that students exposed to high frequency of biology practical classes constituted the group that caused the significance. This implies that high frequency of biology practical classes improves students' knowledge of biological drawings and viceversa.
$\mathrm{HO}_{2}$ There is no significant difference between Teachers' academic qualifications and the knowledge of biological drawings possessed by the students.

Table 3 presents the results of analysis of teachers' qualification influence on the knowledge of biological drawings possessed by senior school students in Oyo state, Nigeria.

Table 3. Independent sample t-test of knowledge of biological drawings of students based on teachers' qualification

\begin{tabular}{lrcccccc}
\hline \multicolumn{1}{c}{ Teachers' qualification } & N & X & SD & df & t & Sig. (2-tailed) & Remark \\
\hline $\begin{array}{l}\text { Students taught by qualified } \\
\text { teachers }\end{array}$ & 419 & 30.28 & 10.26 & & & & \\
$\begin{array}{l}\text { Students taught by unqualified } \\
\text { teachers }\end{array}$ & 238 & 22.95 & 9.8 & 656 & 9.02 & 0.0001 & rejected \\
Total & 657 & & & & & & \\
\hline
\end{tabular}

The results from Table 2 showed $\mathrm{p}=$ .0001 was significant. The implication of this result is that teachers' qualification influences the knowledge of biological drawings possessed by senior school students in the sampled area. Therefore, the null hypothesis which stated that. There was no significant difference between teachers' academic qualifications and the knowledge of biological drawings possessed by the students was rejected. The result of Khurshid's (2008), was in disagreement with the findings of this study. Khurshid's (2008) finding showed no difference in the performances of students taught sciences by qualified and non-qualified teachers. The findings of the following studies where inline with the result of the present study: Omosewo and Abimbola (2007) showed that the teachers' academic qualifications were a necessity for students' performances in physics at the secondary school level of education; Krieg (2005) which concluded that teachers' qualifications affect significantly, students' performance in physics; and Owolabi and Adedayo (2012) that examined the effects of teachers' qualifications on the performance of senior secondary school students in physics, it was discovered that students taught by teachers with high qualifications performed better than those taught by teachers with lower qualifications.

\section{Conclusion}

Based on the results obtained, it was concluded that the knowledge of biological drawings possessed by senior secondary school students exposed to low, medium and high frequency of biological drawings was different. The more frequent students are taught biology practical, the better the knowledge of biological drawings possessed by the students. From the findings of the study, students taught by qualified teachers possessed better knowledge of biological drawings than students taught by unqualified teachers in Senior schools in Oyo State, Nigeria.

Recommendation: In line with the findings obtained from the present research, it was recommended that. Efforts should be made by biology teachers to devote enough time to teach biology practical. Appreciable number of biological drawings should be given to students to draw and mark according to acceptable standards by examinations bodies. Relevant feedbacks should be given to students as well to improve the students' knowledge in the subject. Also, government should employ qualified biology teachers to teach biology in schools. School authorities should as well make to teach biology in schools while employment and allocation of subject should not be biased, respectively.

\section{References}

Akinsolu, A. O. (2010). Teachers and students' academic performance in Nigerian secondary schools: Implications for planning. Florida Journal of Educational Administration \& Policy, 3(2), 86103. https://files.eric.ed.gov/ fulltext/EJ903008.pdf 
Akintola, D. A., Abimbola, I. O., \& Ahmed, A. M. (2018). Assessment of biological drawings among the senior secondary school students in Nigeria. Pakistan Journal of Education, Society and Language, 4(2), 1-14. https://pjsel.jehanf. com/index.php/journal/article/vie $\mathrm{w} / 92 / 79$

Akintola, D. A., \& Ayanlola, G. O. (2019). Effects of analogies strategy on senior secondary school students' achievement in biology in Nigeria. Al-Hikmah University Journal of Education, 6(2), 8-14. https:// www.alhikmah.edu.ng/ajhir/index. php/aje_path/article/view/46

Buddin, R., \& Zamarro, G. (2009). Teacher qualifications and student achievement in urban elementary schools. Journal of Urban Economics, 66(2), 103-115. https://doi.org/10.1016/j.jue.2009 .05 .001

Demir, Y., Sipahi, S., Kahraman, S., \& Yalcin, M. (2007). Preservice science teachers' levels of awareness about topics, units and concepts in primary science curriculum [Fen bilgisi programı öğrencilerinin ilköğretim ikinci kademe fen bilgisi (fen ve teknoloji) müfredatındaki ünite, konu ve kavramlara dair fark. Kastamonu Education Journal, 15(1), 231-240.

Ebubedike, G. U. (2010). Students' perceptions of adequacy of biology practical organized for senior secondary school students in Enugu North local government area (An Unpublished M.Ed. Research Project).

Fakeye, D. O. (2012). Teachers qualification and subject mastery as predictors of achievement in English language in Ibarapapa division of Oyo State. Global Journal of Human Social Science, 12(3), 1-7.

Gbore, L. (2013). Relationship between cognitive entry characteristics and the academic performance of university undergraduates in South West, Nigeria. Journal of Educational and Social Research, 3(1), 19-24. www.richtmann.org/ journal/index.php/jesr/article/vie $\mathrm{w} / 12093$
Khurshid, K. (2008). A study of the relationship between the professional qualifications of the teachers and academic performance of their students at secondary school level. World Academy of Science, Engineering and Technology, 38(1), 445-451. https://citeseerx.ist.psu.edu/viewd oc/download?doi=10.1.1.193.6226 $\&$ rep=rep $1 \&$ type $=$ pdf

Kirschner, P. A., \& van Merriënboer, J. J. G. (2013). Do learners really know best? Urban legends in education. Educational Psychologist, 48(3), 169-183. https://doi.org/10.1080/ 00461520.2013 .804395

Koba, S., \& Tweed, A. (2009). Hard-to-teach biology concepts: A framework to deepen student understanding. NSTA Press.

Kolucki, B., \& Lemish, D. (2011). Communicating with children: Principles and practices to nurture, inspire, excite, educate and heal. UNICEF. https://sites.unicef.org/ cwc/files/CwC_Final_Nov-2011.pdf

Krieg, J. M. (2005). Student gender and teacher gender: What is the impact on high stakes test scores. http://faculty.wwu.edu/ kriegj/Ec on. Documents/Teacher and Student Gender.pdf

Lerner, N. (2007). Drawing to learn science: Legacies of agassiz. Journal of Technical Writing and Communication, 37(4), 379-394. https://doi.org/10.2190/W478M151-4425-GP03

Maagan, D. (2007). Teaching staff survey in elementary schools (2005/2006).

Motlhabane, A. (2014). Online science practical work: How can students do it? In D. Mogari, U. Ogbonnaya, \& K. Padayachee (Eds.), ISTE International Conference on Mathematics, Science and Technology Education. University of South Africa. https://repository.nwu.ac.za/

Mubenga, P. T. (2006). Closing the achievement gap between African American children and their Caucasians counterparts using collaboration learning setting. https://files.eric.ed.gov/fulltext/E D490762.pdf 
Okoli, J. N. (2006). Effects of investigative laboratory approach and expository method on acquisition of science process skills by biology students of different levels of scientific literacy. Journal of Science Research Association of Nigeria, 41, 79-88.

Olagunju, A. M., Adesoji, F. A., Iroegbu, T. O., \& Ige, T. A. (2003). Innovations in science teaching for the new millennium. Education this millennium-innovations in theory and practice. Macmillan publisher Nigeria.

Omosewo, E. O. (2010). Poor practical classes: teachers implementation of the practical components of senior secondary Physics curriculum with strategies for improved Physics in Kwara State.

Omosewo, E. O., \& Abimbola, I. O. (2007). Views of Nigerian science teacher educators on the American minimum professional knowledge standards for science teacher educators. Institute Journal of Studies in Education, 1(4), 106-112.

Owolabi, O. T., \& Adedayo, J. O. (2012). Effect of teacher's qualification on the performance of senior secondary school physics students: Implication on technology in Nigeria. English Language Teaching, 5(6), 72-77. https:// doi.org/10.5539/elt.v5n6p72

Oyelekan, O. S., Igbokwe, E. F., \& Olorundare, A. S. (2017). Science teachers' utilisation of innovative strategies for teaching senior school science in Ilorin, Nigeria. Malaysian Online Journal of Educational Sciences, 5(2), 49-65. https://mojes.um.edu.my/article/v iew/12624/8119
Tașdemir, A., \& Demirbaș, M. (2010). The level of correlation of concepts that primary students seen topics in science and technology class with daily life. Journal of Human Sciences, 7(1), 124-148. https://jhumansciences.com/ojs/index.php /IJHS/article/view/509

Tournaki, N., Lyublinskaya, I., \& Carolan, B. V. (2009). Pathways to teacher certification: Does it really matter when it comes to efficacy and effectiveness? Action in Teacher Education, 30(4), 96-109. https://doi.org/10.1080/01626620 .2009 .10734455

Uche, F. C. (2010). Identification of laboratory facilities and teaching methods used in teaching biology in secondary schools in Udi Local Government Area of Enugu state.

Watt, S. J., Therrien, W. J., Kaldenberg, E., \& Taylor, J. (2013). Promoting Inclusive Practices in Inquiry-Based Science Classrooms. TEACHING Exceptional Children, 45(4), 40-48. https://doi.org/10.1177/00400599 1304500405

West African Examinations Council. (2014). Chief examiners' report in biology SSCE.

West African Examinations Council. (2015). Chief examiners' report in biology SSCE.

West African Examinations Council. (2016). Chief examiners' report in biology SSCE.

West African Examinations Council. (2017). Chief examiners' report in biology SSCE.

West African Examinations Council. (2018). Chief examiners' report in biology SSCE. 